\title{
A Critical Review of Organizational Culture on Employee Performance
}

\author{
Ananta Narayana \\ Department of Humanities and Social Sciences, Motilal Nehru National Institute of Technology, Allahabad, India \\ Email address: \\ ananta.narayana20@gmail.com

\section{To cite this article:} \\ Ananta Narayana. A Critical Review of Organizational Culture on Employee Performance. American Journal of Engineering and \\ Technology Management. Vol. 2, No. 5, 2017, pp. 72-76. doi: 10.11648/j.ajetm.20170205.13
}

Received: September 1, 2017; Accepted: October 8, 2017; Published: November 7, 2017

\begin{abstract}
The study attempts to examine the effect of organizational culture on employee performance and its evaluation has been identified by certain researcher's research. The main aim of research article is to identify and determine strong relationship between organizational culture and employee performance. Literature review is adopted as methodology to review the culture of an organization upon employee performance. The owners and top management of an organization generally tends to have a large impact on establishing a culture. The Organization's culture results from the interaction between the top management's assumptions and shared visions of cultural values and human behavior and what the employees of the organization learn from their own experiences. Managers relate organizational culture and employee performance to each other as they help in providing competitive advantage to the organizations. Hence Organizational culture plays a vital role in enhancing employee performance. Organizational culture must be binding on all members and employees of the organization as this will encourage uniformity among members of the organization and this enhance commitment, group efficiency and overall performance of employees.
\end{abstract}

Keywords: Organizational Culture, Employee Performance, Impact, Employee Commitment, Organizational Goals

\section{Introduction}

Organizational culture defines the way of employees' complete tasks and interacts with each other within the organization. The cultural pattern comprises various beliefs, values, rituals and symbols that govern the operating style of the people within a company. Organization culture binds the employees together and provides a direction for the growth of company. Organizational cultures can have varying impacts on employee performance and motivation levels. Oftentimes, employees work harder to achieve organizational goals if they consider themselves to be part of the organizational culture. Different cultural background operating in one company can also impact employee performance. Strong corporate cultures indicate that employees are like-minded and hold similar beliefs and ethical values. When these beliefs and ethical values align with business objectives, they can prove to be effective in building teams because rapport and trust quickly ensues. The bonds that the teams build help them avoid conflicts and focus on task completion. Strong corporate cultures ease communication of roles and responsibilities to all individuals. Employees know what is expected of them, how management assesses their performance and what forms of rewards are available. The objective of this study is to examine the effect of organizational culture on employee performance and in line with this objective this research study is poised towards providing answers to the following questions, does organizational culture have any effect on employee performance and in what way does organizational culture effects employee performance. The study is based on secondary sources and for that critical review of various research papers related to the study has been done.

\section{Review of Literature}

The aim of the literature review is to examine the existing research to explore the links between organization culture and employee performance. There has been significant research in the literature to explore the effect of organizational culture on employee performance in which some of them are reviewed. Culture is an organization 
ideology, or "the traditions and beliefs of an organization that distinguish it from other organizations and infuse a certain life into the skeleton of its structure" [29]. Culture is an active living phenomenon through which people jointly creates and recreates the worlds in which they live [30]. Culture is conceptualized as shared beliefs and values within the organization that helps to shape the behavior patterns of employees [18]. Organizational culture has been defined as the "normative glue" that holds an organization together [43]. Organization culture as the drive that recognizes the efforts and contributions of the organizational members and provides holistic understanding of what and how is to be achieved, how goals are interrelated, and how each employee could attain goals [13]. Hofstede summarizes organization culture as collective process of the mind that differentiates the members of one group from the other one. Thus the above concept asserts that organizational culture could be the means of keeping employees in line and exhilarating them towards organizational objectives $[15,16]$. Schein outlined the organizational culture as overall phenomenon of the organization such as natural settings, the rite and rituals, climate and values of the company [36]. He further defined organizational culture as a dynamic force within the organization which is revolving, engaging and interactive and it shaped up by the employees and managements gestures, behaviors and attitudes. Earlier studies indicated a link between organizational culture and employees' performance [37]. Magee argued that organizational culture is inherently connected to organizational practices which in turn influence employees' performance [23]. Hellriegel \& Slocum contend that organizational culture can enhance employees' performance if what sustains it can be understood. Thus, the culture of an organization acquaints employees with the firm's history as well as current methods of operation that guide employees on expected and acceptable future organizational behaviors and norms [14]. Effective human resource system is based on supporting values that create a positive impact on employees' attitudes and behaviors which in turn influence their performance [11]. From numerous "culture surveys" it has been claimed that employee performance can be improved by developing and creating certain kinds of organizational cultures [35]. Organizational culture is theoretically related to performance and has positive influence on it [24]. Bowen \& Ostroff observed the role of culture in nurturing, sustaining and enhancing employees' performance in organizations [27]. Organizational culture aids coordination of assignments and minimizes inefficiency in resource utilization. Employees need a supportive organizational culture to attain their individual objectives [17]. Organizational culture functions as the internal integration and coordination between a firm's operations and its employees, where it fails to fulfill these functions to a satisfactory level, employees may be influenced negatively [12]. A positive culture supports adaptation and enhances employees' performance by motivating, shaping and channeling their behaviors towards the attainment of corporate objectives [6]. A firm's mission reflects its ultimate long term objective which is accomplished by conducting integrated operational and behavioral activities [18]. A firm's performance improves if it has a clear sense of purpose and commitment towards its mission [18]. The performance of an organization is dependent on the degree to which the values of it are widely shared [13]. Ogbonna widely argued that shared and strongly held values enable management to predict employee's reactions to certain strategic options and by reducing these values, the consequences maybe undesirable [31]. Denison found, in his study of organizational culture, that companies with a participative culture reaped a return on investment, which averaged nearly twice that of firms with less efficient cultures. His conclusion was that cultural and behavioral aspects of organizations were intimately linked to both shortterm performance and long-term survival [8]. Deal defines organizational culture as values, beliefs and behaviors that differentiate one organization from another. Performance of any organization sets it apart from other organizations. The term performance is often used to describe everything from efficiency and effectiveness to improvement [7]. Previous literature studies obviously show evidence of positive relationship between organization culture and its performance. Satisfaction and positive attitude can be achieved through maintaining a positive organizational environment, such as by providing good communication, autonomy, participation, and mutual trust resulting superior employee performance [1]. Mc Gregor explains that the satisfaction and attitudes of the employees are important factors in determining their behaviors and responses at work and through these behaviors and responses, organizational effectiveness can be achieved. Thus the satisfaction and well being of employees can result in organizational effectiveness through silent productivity related behaviors of employs [28]. Druckman argues that loyalty and commitment both interpret an emotional bonding between the individual and his or her cultural group and, as such, imply a willingness to put forth exertion and make sacrifices on behalf of that group [10]. O'Reilly suggests that employee's commitment to an organization will be more dedicated because they care about their organization's fate, and their caring heightens the power of organizational norms to control their behavior [32]. Daft that Organizations Culture can play an important role in creating such an environment that enables learning and innovative response to challenges, competitive threats, or new opportunities. Thus, creating and influencing an adaptive culture is one of a manager's most important jobs [6]. The authors Meyer, Stanely, Hercovitch \& Topolnytsky conducted meta-analyses to assess relations among affective, continuance, and normative commitment to the organization [26]. They found that the three forms of commitment are related yet distinguishable from one another as well as from job satisfaction, job involvement, and occupational commitment [26]. Motowidlo \& Van Scotter proposed two dimensions of employee performance. Task performance (or technical job performance) is the behaviour associated with maintaining and servicing an organization's technical core. 
Contextual performance (or interpersonal job performance) is a function of one's interpersonal skill knowledge that supports the broader social environment in which the technical core must function [27]. Organizational culture too, plays an important role in generating commitment and enhancing performance $[7,21,33]$. In particular, studies in various industries and countries showed that innovative and supportive cultures had strong positive effects on commitment and job satisfaction, while bureaucratic cultures had a negative impact $[3,4,5,19,20,21,22,34,41,45,46$, 47]. Yousef also investigated the role of organizational commitment as a mediator of the relationships between leadership behaviour with job satisfaction and performance, specifically in a multicultural, non-western country. Results from various organizations in the United Arab Emirates suggest (in support of many western studies) that those who perceive their superiors as adopting consultative or participative leadership behaviour are more committed to their organizations, more satisfied with their jobs, and their performance is high [47]. According to Tanase organizational culture is an Issue of Escalating importance when structural changes like downsizing, merging \& restructuring occurs which leads to increase in complexity and unpredictability of the fast changing external environment. He continues that understanding, assessing and managing organizational culture can help the organizations to achieve both stability and adaptability [42]. Organizational Culture as a more or less shared way of being, thinking and acting of a collective of people in coordination with reciprocal expectations \& that provide some predictability with certain specific in each organization [40, 44, 38, 25].

\section{Findings}

Findings of the study are as follows:

a. Organizational culture provides employees with a sense of guidance, direction \& expectations that keep employees on task \& make them understand about their role and responsibilities.

b. Organizational culture creates a positive impact on employee's attitude \& behavior and in turn employees accomplish task prior to established deadlines.

c. Organizational culture helps to unite employees of different demographics, promote better understanding, better coordination $\&$ less conflict.

d. Organizational culture aids coordination of assignment $\&$ minimizes inefficiency in resource utilization.

e. Organizational culture enables internal integration \& coordination between companies operation \& its employees so that employees can influenced positively.

f. Organizational culture enhances employee's performance by motivating, shaping \& channeling their behavior towards the attainment of organization's objectives.

g. Organizational culture shows clear sense of purpose \& commitment towards organization mission which enhances employee's performance towards goal attainment. h. Positive organizational culture provides satisfaction, positive attitude, mutual trust, autonomy, good communication which results superior employee performance.

i. Organizational culture helps to keep employee motivated and loyal to the management of the organization, they make employees eager to contribute to the organizations success and feel them sense of accomplishment.

j. Organizational culture enables employees to perform at their best to earn recognition \& appreciation from their superiors which in turn increases the quality of their work \& enhances their performance.

$\mathrm{k}$. Organizational culture plays an important role in creating environment of learning, innovative response to challenge competitive threats \& new opportunities which ultimately enhances employee's performance.

1. Organizational culture should be affective, continuance, and normative job satisfaction, job involvement, and occupational commitment.

m. Organizational culture plays an important role in generating commitment and enhancing performance.

\section{Recommendations \& Conclusion}

\subsection{Recommendations}

Every individual has different culture and beliefs that he/she works with and when he/she joins an organization that has a completely different culture and beliefs from his own, he/she should be allowed to internalize himself first with the organization's culture and values to know whether he/she can manage with them or not. It is the ability of the employee to cope with the organizations culture that will determine how he/she will perform on his job. Organizational culture must be binding on all member and employees of the organization as this will encourage uniformity among employees of the organization and thus enhance commitment and group efficiency. In cases where an organizational culture must be changed, employees must first of all be notified and made to learn the modification of the old culture as this will affect their performance positively.

\subsection{Conclusion}

In this study it was tried to look at the effect of organizational culture on employee's performance with evidence of various related literatures. A good organizational culture always considered the employees as an integral part of the growth process of the organization. An organization fosters the employee commitment towards the organization. Employees align their goals and objectives with organizational goals and feel responsible for the overall wellbeing of the organization. As their efforts are in turn appreciated by the management and suitably rewarded, and they have immense job satisfaction. In such organizational cultures, the employees are committed to achieving their goals and thus have a positive effect on the overall 
performance of the organization. Organizational culture enables internal integration \& coordination between organization and its employees and it creates the environment of learning, competition, opportunities, positive attitude, mutual trust, better understanding, less conflict, increases the quality of work, sense of accomplishment and performance enhancement. What we deducted from this study is that organizational culture is very important in every organization and it enhances employee's performance resulting employee's commitment which helps the organization to prosper \& flourish and influence the level of organizational goal in a positive way.

\section{References}

[1] Argyris, C. (1964). Integrating the individuals and the organizations. New York: Wiley.

[2] Bowen, D. E., \& Ostroff, C. (1989). Understanding HRM-firm performance linkages: The role of "Strength" of the HR system. Academy of Management Review, 29, 203-22.

[3] Brewer, A. (1993). Managing for Employee Commitment, Longman, and London.

[4] Brewer, A. (1994). The Responsive Employee, Allen \& Unwin, Sydney.

[5] Brewer, E. W. \& Clippard, L. F. (2002). Burnout and job satisfaction among Student Support Services personnel. Human Resource Development Quarterly, 13 (2), 169-86.

[6] Daft, R. L. (2010). Organization Theory and Design. Singapore: Info Access \& Distribution Ltd.

[7] Deal, T., \& Kennedy, A. A. (1982). Corporate culture: Rites and rituals of organizational life. Reading, MA: Addison-Wesley.

[8] Denison, D. R. (1984). Bringing corporate culture to the bottom line. Organizational Dynamics, 3(2), 5-22.

[9] Denison, D. R. (1990). Corporate Culture and Organizational Effectiveness. New York, NY: John Wiley \& Sons.

[10] Druckman, D., \& Bjork, Robert A. (1994). Learning, Remembering, Believing: Enhancing Human Performance. Washington, D. C.: National Academy Press.

[11] Ferris, G. R., Arthur, M. M., Berkson, H. M., Kaplan, D. M., Harrell-Cook, G., \& Frink, D. D. (1998). Toward a social context theory of human resource management-organizational effectiveness relationship. Human Resource Management Review, 8, 235-264.

[12] Furnham, A. \& Gunter, B. (1993). Corporate Assessment: Auditing \& Company Personality. London: Routledge.

[13] Gordon, G. \& Cummins W. (1979). Managing management climate. Toronto, Canada, Lexington Books.

[14] Hellriegel, D. \& Slocum, J. M. (2009). Organizational Behavior (9th Edition). Sydney: Thomson Learners.

[15] Hofstede, G. (1980a). Culture's consequences: international differences in work related values Beverly Hills, CA: Sage.

[16] Hofstede, G. (1980b). Motivation, Leadership and Organization: do American theories apply abroad?
Organizational Dynamics, 9 (1), 42-63.

[17] Kopelman, R. E., Brief, A. P., \& Guzzo, R. A. (1990). The role of climate and culture in productivity. In B. Schneider (Ed.), Organizational climate and culture. 282-318).

[18] Kotter, J. P. \& Heskett, J. L. (1992). Corporate culture and performance. New York: Free Press.

[19] Kratrina, S. (1990). Organizational culture and head nurse leadership: the relationship to nurse's job satisfaction and turnover in hospital settings, unpublished $\mathrm{PhD}$ thesis, College of Education, Georgia State University, Atlanta, GA.

[20] Krausz, M., Koslowsky, M., Shalon, N. \& Elyakim, N. (1995). Predictors of intention to leave the ward: the hospital and the nursing profession: a longitudinal study. Journal of Organizational Behaviour, 16, 277-88.

[21] Lok, P. \& Crawford, J. (2001). Antecedents of organizational commitment and the mediating role of job satisfaction. Journal of Managerial Psychology, 16 (7-8), 594-613.

[22] London, M. \& Larsen, H. (1999). Relationships between feedback and self-development. Group and Organization Management, Vol. 24 No. 1, pp. 5-27.

[23] Magee, K. C. (2002). The impact of organizational culture on the implementation of performance management. Doctoral dissertation. Available from Dissertations and Theses database (UMI No. 3047909).

[24] Martin, J. and Siehl, C. (1990). Organizational Culture: A Key to Financial Performance. In B. Schneider (Ed.). Organizational Climate and Culture, San Francisco, CA: Jossey-Bass, 241-281.

[25] Martin, J. \& Frost, P. (2012). The organizational Culture was Games: A Struggle for intellectual dominance in sociology of organizations: Structure \& Relationships, Godwyn, M. \& Gittell J. H (Ed.) Sage publications, Thousand Oaks, C. A., pp 315-336.

[26] Meyer, J. P., Stanely, D. J., Hercovitch, L., Topolnytsky, L. (2002). Affective, Continuance and Normative Commitment to the Organization: A Meta-analysis of Antecedents, Correlates, and Consequences. Journal of Vocational Behavior, 61(1), 20-52.

[27] Motowidlo, S. J. \& Van Scotter, J. R. (1994). Evidence that task performance should be distinguished from contextual performance. Journal of Applied Psychology, 79, 475-80.

[28] McGregor, D. (1960). The human side of enterprise. NY: McGraw-Hill.

[29] Mintzberg, H. (1979). Structures in Fives, Designing Effective Organizations. Prentice-Hall, Englewood Cliffs, NJ.

[30] Morgan, G. (1997) Images of Organization, Thousand Oaks: Sage Publications.

[31] Ogbonna, E. (1993). Managing Organizational Culture: Fantasy or Reality? Human Resource Management Journal, $3(2), 42-54$

[32] O'Reilly, C. (1989). Corporations, Culture and Commitment: motivation and social control in organizations. California Management Review, summer.

[33] Peters, T. \& Waterman, R. (1982), In Search of Excellence, Harper \& Row, New York, NY. 
[34] Rashid, M. Z. A., Sambasivan, M. \& Rahman, A. A. (2004). The influence of organizational culture on attitudes toward organizational change. Leadership \& Organization Development Journal, 25(2), 161-79.

[35] Sackmann, S. A., \& Bertelsmann S. (2006). Success Factor Corporate Culture. Developing a Corporate Culture for High Performance and Long-term Competitiveness, Six Best Practices. Kinndle Edition.

[36] Schein, E. H. (1990) Organizational Culture, American Psychologist, 43 (2), 109-119.

[37] Schein, E. H. (2004). Organizational culture and leadership (3rd Ed.). Jossy-Bass.

[38] Schein, E. H. (2010). Organizational culture \& leadership. $4^{\text {th }}$ (Ed.), John Wiley and Sons, New York, USA, ISBN-13 9780470640579, pp 464.

[39] Schneider (Ed.). Organizational Climate and Culture, San Francisco, CA: Jossey-Bass, 241-281.

[40] Serpa, S. (2016). An overview of the concept of organizational culture. International business management, 10(1), 51-61.

[41] Silverthorne, C. (2004). The impact of organizational culture and person-organization fit on organizational commitment and job satisfaction in Taiwan. Leadership \& Organization Development Journal, 25(7), 592-9.

[42] Tanase, I. A (2015). The importance of organizational culture based on culture transfer. Proceedings of the $9^{\text {th }}$ International management conference "Management \& innovation for competitive advantage". November $5^{\text {th }}-6^{\text {th }}$, Bucharest, Romania.

[43] Tichy, N. M. (1982) Managing Change Strategically: The Technical, Political, and Cultural Keys, Organizational Dynamics (autumn), pp. 59-80.

[44] Torres, L. L. (2011). Organizational culture in educational context. In perspective of organizational analysis of schools, Lima, L. C (Ed.) Manuel Leao Foundation, Vila Nova de Gaia, Portugal.

[45] Trice, H. \& Beyer, J. M. (1993). The Cultures of Work Organization, Prentice-Hall, Englewood Cliffs, NJ.

[46] Wallach, E. J. (1983). Individuals and organizations: the cultural match. Training and Development Journal, 37, 29-36.

[47] Yousef, D. A. (2000). Organizational commitment: a mediator of the relationships of leadership behaviour with job satisfaction and performance in a non-western country. Journal of Managerial Psychology, 15 (1), 6-28. 